\title{
Free Amino Acids and Calcium, Magnesium and Zinc Levels in Friedreich's Ataxia
}

\author{
R.J. Huxtable, P. Johnson, S.E. Lippincott
}

\begin{abstract}
Free amino acid levels and zinc, magnesium and calcium content have been determined in autopsy samples of 9 areas of the brain, two skeletal muscles, and the right ventricle, left ventricle and septum of the heart of a Friedreich's ataxia subject.

RÉSUMÉ: Nous avons dosé, à l'autopsie, le niveau des acides aminés libres et celui du zinc, magnésium et calcium dans des échantillons de 9 régions du cerveau, deux muscles squelettaux, le ventricule droit, le ventricule gauche et le septum cardiaque d'un sujet souffrant de l'ataxie de Friedreich.
\end{abstract}

Can. J. Neurol. Sci. 1984; 11:616-619

Little information is available on free amino acid and metal ion content of tissues of Friedreich's ataxia patients. Free amino acid levels in the brains of two patients have been reported (Huxtable et al., 1979), but no report has yet appeared on metal ion content of the brain. Information of this nature is needed, however, to test certain hypotheses concerning biochemical defects in Friedreich's ataxia. Thus, it has been proposed that the cardiomyopathy invariably found associated with Friedreich's ataxia is due to a calcium overload defect (Huxtable, 1978), It has also been suggested that a defect in taurine regulation occurs in Friedreich's ataxia (Filla et al., 1978; Barbeau, 1980, 1982; Barbeau et al., 1982).

In this paper, we report values on free amino acid and metal ion concentrations in brain, heart, and muscle samples of a patient dying of Friedreich's ataxia.

\section{MethodS}

\section{Clinical summary}

Autopsy samples were obtained from a patient dying with Friedreich's ataxia. The patient was a 19-year-old white male who had been diagnosed as having Friedreich's ataxia at the age of 4 years. Poorly differentiated lymphoblastic lymphoma was diagnosed at age 18 years when he developed a superior venal caval syndrome. At that time he had severe scoliosis, and difficulty in walking and making fine movements with his hand because of ataxia. There was also slowness of speech. An echocardiogram showed left ventricular hypertrophy. Treatment included vincristine, adriamycin, and prednisone. Shortly after discharge following this therapy the patient developed a mur- mur with tachycardia and tachypnea that was thought to be an adriamycin-induced aggravation of his cardiomyopathy. Consequently, no further adriamycin was given. He had not received intrathecal methyltrexate because of his neurological problems; however, he returned 10 months later with headache when a lumbar puncture showed 600 blasts $/ \mathrm{mm}^{3}$. He was treated then with intrathecal methyltrexate and systemic vincristine as well as 6-mercaptopurine, methyltrexate, L-asparaginase, and Septa (a mixture of trimethoprim and sulfamethoxazole). Subsequently he developed recurrent leptomeningeal involvement with loss of vision in the right eye, diminished vision in the left eye and a 6th cranial nerve palsy. A seizure disorder developed and he died 2 months later.

\section{Pathological findings}

At autopsy, lymphoma of a poorly differentiated lymphoblastic type was found throughout the entire body with massive diffuse lymphadenopathy and splenomegaly. Of particular note was a lymphomatous infiltrate in the leptomeninges. In addition, there were multiple petechiae and ecchymoses suggesting a bleeding disorder.

Pathologic findings relating to Friedreich's ataxia included gliosis with tract degeneration in the cortical spinal, anterior and posterior spinal cerebellar and posterior column tracts as well as the gracile and cuneate nuclei. There was severe scoliosis. Also, there was marked hypertrophy of the left ventricle $(1.8 \mathrm{~cm})$.

\section{Analyses}

The amino acid analyses were performed as previously described (Huxtable et al., 1979). Ion analyses were performed

From the Departments of Pharmacology and Pathology, University of Arizona Healths Sciences Center, Tucson.

Reprint requests for the complete supplement (Phase 3. Part 3) to: Prof. André Barbeau, Clinical Research Institute of Montreal, 110 Pine Avenue West, Montreal. Quebec. Canada H2W IR7. 
by atomic absorption spectroscopy at the University of Arizona Analytical Center (Azari et al., 1980).

\section{RESULTS AND Discussion}

A wealth of research has been performed on Friedreich's ataxia over the past ten years (summarized by Barbeau, 1980 , 1982). Despite intensive investigation, basic biochemical indices are still difficult to establish for Friedreich's ataxia, due to the poor availability of biopsy or autopsy material. We feel, therefore, that the amino acid and metal determinations we report herein, although derived from only one case of Friedreich's ataxia, are of value in that they have rarely if ever been performed before (Huxtable et al., 1979).

Total tissue contents of calcium, magnesium and zinc for brain and muscle are reported in Tables $I$ and 2 . It has been suggested that the cardiomyopathy of Friedreich's ataxia may be secondary to a dysfunction in calcium regulation in the heart, whereby there is abnormally increased calcium flux into the myocyte (Huxtable, 1978). Data concerning the calcium content of Friedreich's ataxia hearts are sparse and inconsistent. One study reported areas of intracellular calcification in the heart from a Friedreich's ataxia patient at autopsy (SanchezCasis et al., 1976). A subsequent study of three hearts obtained from Friedreich's ataxia patients, however, reported finding no myocardial calcium deposits, as determined by histological analysis using a Von Kossa stain (Lamarche et al., 1980).

Different authors have reported calcium levels in human hearts ranging from 40 to $155 \mu \mathrm{g} / \mathrm{g}$ wet weight (summarized in Lyengar et al., 1978). Where values were originally reported

Table 1: Metal Ion Content of Heart and Skeletal Muscle in Friedreich's Ataxia

\begin{tabular}{|c|c|c|c|}
\hline & \multicolumn{3}{|c|}{$\mu \mathrm{g} / \mathrm{g}$ wet weight of tissue } \\
\hline & Ca & $\underline{\mathbf{M g}}$ & $\underline{\mathbf{Z n}}$ \\
\hline Intercostal muscle & 116 & 155 & 52 \\
\hline Pectoralis major & 19.4 & 180 & 52 \\
\hline Left ventricle & 40 & 188 & 29.6 \\
\hline Septum & 96 & 160 & 30.0 \\
\hline Right ventricle & 132 & 120 & 27.6 \\
\hline \multicolumn{4}{|c|}{ Table 2: Metal Ion Content of Brain in Friedreich's Ataxia } \\
\hline & \multicolumn{3}{|c|}{$\mu \mathrm{g} / \mathrm{g}$ wet weight of tissue } \\
\hline & $\mathbf{C a}$ & Mg & $\mathbf{Z n}$ \\
\hline Anterior cerebellar vermis & 16 & $\overline{140}$ & $\overline{16.0}$ \\
\hline Dentate nucleus & 96 & 204 & 26.8 \\
\hline Posterior cerebellar vermis & 29 & 136 & 14.8 \\
\hline Cerebral cortex & 22 & 128 & 15.2 \\
\hline Cerebral hemisphere & 112 & 188 & 23.2 \\
\hline Precentral gyrus & 160 & 190 & 47 \\
\hline Inferior olivary nucleus & 20 & 230 & 41 \\
\hline Red nucleus & 390 & 450 & 56 \\
\hline
\end{tabular}

per ash weight or per dry weight, they have been converted to per wet weight using the conversion factors of Lyengar et al. (1978). The median value found was $57 \mu \mathrm{g} / \mathrm{g}$ wet weight. On the basis of this, it would appear that right ventricular calcium content in our patient is distinctly high, with the left ventricle having low to normal values. The mean of the averages for calcium content of skeletal muscle summarized by Lyengar et al. (1978) is $66 \mu \mathrm{g} / \mathrm{g}$ wet weight. Information on variation from muscle to muscle, however, is not given. Of the two muscles we examined, the intercostal would appear to be abnormally high in calcium content, and the pectoralis major would appear to be abnormally low in calcium.

Average zinc values reported by various laboratories are 34 $\pm 21 \mu \mathrm{g} / \mathrm{g}$ wet weight for the heart (standard deviation of means of 18 groups), and for muscle $54 \pm 11$ (11 groups). The values we report in Table 1, therefore, fall in the middle of the expected range. Magnesium levels, on the other hand, tend to be low. The average values reported for muscle are $224 \pm 46$, and for heart $192 \pm 44$ (Lyengar et al., 1978).

We find considerable variation from region to region in the calcium content of the brain (Table 2). These values may be compared to the average and deviation of 9 sets of determinations for the brain of $128 \pm 19 \mu \mathrm{g} / \mathrm{g}$ (Lyengar et al., 1978). Corresponding values for magnesium and zinc are $173 \pm 129$ (mean of 19 sets) and $13 \pm 4$ (mean of 16 sets), respectively.

The free amino acid contents for the same regions are shown in Tables 3 and 4 . The values for muscle may be compared to those of Bergstrom et al. (1974). Amino acid values in the brains of Friedreich's ataxia patients have been reported before (Huxtable et al., 1979). The major observation was that glutamate levels remain relatively invariant from region to region. As can

Table 3: Free Amino Acid Content of Heart and Skeletal Muscle Regions in Friedreich's Ataxia

\begin{tabular}{|c|c|c|c|c|c|}
\hline & \multicolumn{5}{|c|}{$\mu$ mole/g wet weight } \\
\hline & $\begin{array}{c}\text { Intercostal } \\
\text { muscle }\end{array}$ & $\begin{array}{c}\text { Pectoralis } \\
\text { major }\end{array}$ & $\begin{array}{c}\text { left } \\
\text { ventricle } \\
\end{array}$ & septum & $\begin{array}{c}\begin{array}{c}\text { right } \\
\text { ventricle }\end{array} \\
\end{array}$ \\
\hline Pser & 0.11 & 0.09 & 0.12 & 0.14 & 0.11 \\
\hline Tau & 6.71 & 14.30 & 6.91 & 7.13 & 3.33 \\
\hline Asp & 0.18 & 0.26 & 0.33 & 0.27 & 0.26 \\
\hline Thr & 0.42 & 0.79 & 0.82 & 0.98 & 0.54 \\
\hline Ser & 0.52 & 1.06 & 1.45 & 1.65 & 0.89 \\
\hline Asn & 0.52 & 0.51 & 1.22 & 0.97 & 0.79 \\
\hline Gln & 5.72 & 8.57 & 13.43 & 14.83 & 6.68 \\
\hline Pro & 0.94 & 1.39 & 0.92 & 0.98 & 0.89 \\
\hline Glu & 1.22 & 1.74 & 15.74 & 20.08 & 8.89 \\
\hline Gly & 1.70 & 2.16 & 2.07 & 2.24 & 1.80 \\
\hline Ala & 3.04 & 3.76 & 12.73 & 12.79 & 7.50 \\
\hline Val & 0.67 & 0.92 & 0.90 & 1.11 & 0.67 \\
\hline $1 / 2$ cys & 0.14 & 0.15 & 0.23 & 0.26 & 0.21 \\
\hline Met & 0.13 & 0.24 & 0.38 & 0.43 & 0.16 \\
\hline Isoleu & 0.24 & 0.32 & 0.48 & 0.45 & 0.28 \\
\hline Leu & 0.52 & 0.69 & 1.34 & 1.45 & 0.75 \\
\hline Tyr & 0.26 & 0.34 & 0.46 & 0.48 & 0.29 \\
\hline Phe & 0.41 & 0.51 & 0.88 & 0.96 & 0.48 \\
\hline B-AIB & 0.97 & 1.23 & 1.22 & 1.06 & 1.10 \\
\hline
\end{tabular}


be seen from Table 4, the same phenomenon is found in the patient reported on here. Thus, the mean variation for the glutamate values reported in Table 4 is $14 \%$, compared with $36 \%$ for the taurine values, and $48 \%$ for the GABA values.

The ratios of concentrations of neuroactive amino acids may be of greater relevance than their absolute amounts (van Gelder, 1978). Certain ratios are reported in Table 5. The glutamate: glutamine ratio is significantly decreased in Friedreich's ataxia brains for all areas examined. Glutamine is largely contained within the glia, where one of its functions is to serve as a reservoir for maintaining synaptosomal glutamate content (van Gelder, 1978). The loss of the region to region variation in glutamate levels combined with the fall in glutamate:glutamine ratio suggests that Friedreich's ataxia brains suffer some anatomical or biochemical change in glutamate-containing synapses.

\begin{tabular}{|c|c|c|c|c|c|c|c|c|}
\hline $\mathrm{ACV}$ & DN & PCV & $\begin{array}{l}\text { Region } \\
\text { CC }\end{array}$ & $\mathbf{C H}$ & PG & ION & $\mathbf{R N}$ & $\mathrm{SC}$ \\
\hline 0.33 & trace & 0.33 & 0.25 & trace & 0.26 & 1.11 & trace & 0.15 \\
\hline 3.67 & 1.82 & 3.47 & 1.54 & 4.12 & 1.41 & 2.70 & 2.49 & 2.62 \\
\hline 1.71 & 1.37 & 1.68 & 2.63 & 1.92 & 2.29 & 1.44 & 3.59 & 2.38 \\
\hline 11.47 & 18.25 & 11.73 & 11.41 & 11.42 & 11.65 & 10.30 & 16.89 & 13.60 \\
\hline 0.14 & trace & 0.33 & 0.17 & 0.43 & trace & 1.03 & 0.32 & 1.32 \\
\hline 9.99 & 7.40 & 9.90 & 10.79 & 9.56 & 9.13 & 7.69 & 10.21 & 10.51 \\
\hline 2.72 & 2.29 & 2.30 & 1.79 & 2.69 & 1.45 & 4.40 & 2.89 & 6.89 \\
\hline 3.45 & 3.43 & 3.27 & 3.00 & 3.17 & 2.64 & 4.74 & 4.98 & 6.07 \\
\hline 0.56 & 0.32 & 0.63 & 0.63 & 0.50 & 0.36 & 1.49 & 0.73 & 1.75 \\
\hline 1.20 & 0.90 & 1.14 & 1.00 & 1.29 & 0.69 & 1.68 & 1.43 & 3.06 \\
\hline 0.67 & 0.47 & 0.48 & 0.35 & 0.61 & 0.23 & 0.56 & 0.55 & 1.01 \\
\hline 0.90 & 0.71 & 0.61 & 0.57 & 0.80 & 0.48 & 0.59 & 1.02 & 1.49 \\
\hline 2.09 & 4.14 & 1.67 & 1.80 & 1.42 & 1.56 & 1.21 & 3.28 & 1.38 \\
\hline
\end{tabular}

Abbreviations: ACV anterior cerebellar vermis; DN dentate nucleus; $\mathrm{PCV}$ posterior cerebellar vermis; $\mathrm{CC}$ cerebral cortex; $\mathrm{CH}$ cerebellar hemisphere; PG precentral gyrus; ION inferior olive nucleus; RN red nucleus; SC spinal cord.

\begin{tabular}{lcccc}
\hline \multicolumn{5}{l}{ Table 5: Selected Amino Acid Ratios } \\
\hline \hline Control & $\begin{array}{c}\text { CH } \\
\text { (4) }\end{array}$ & $\begin{array}{c}\text { PCV } \\
\text { (4) }\end{array}$ & $\begin{array}{c}\text { ACV } \\
(\mathbf{4})\end{array}$ & $\begin{array}{c}\text { DN } \\
(3)\end{array}$ \\
\hline Tau/Glu & $0.24 \pm 0.14$ & $0.18 \pm 0.11$ & $0.37 \pm 0.42$ & $0.23 \pm 0.15$ \\
Tau/GABA & $1.57 \pm 0.63$ & $1.00 \pm 0.52$ & $1.05 \pm 0.50$ & $0.51 \pm 0.36$ \\
GABA/Glu & $0.14 \pm 0.04$ & $0.16 \pm 0.04$ & $0.32 \pm 0.30$ & $0.45 \pm 0.04$ \\
Glu/GIn & $1.94 \pm 0.55$ & $2.32 \pm 1.23$ & $2.20 \pm 1.05$ & $1.22 \pm 0.38$ \\
\hline Friedreich's & & & & \\
Ataxia & $(3)$ & $(3)$ & $(3)$ & $(3)$ \\
\hline Tau/Glu & $0.43 \pm 0.34$ & $0.35 \pm 0.23$ & $0.37 \pm 0.18$ & $0.25 \pm 0.43$ \\
Tau/GABA & $2.90 \pm 1.32$ & $2.08 \pm 1.02$ & $1.76 \pm 0.54$ & $0.44 \pm 4.24$ \\
GABA/Glu & $0.15 \pm 0.04$ & $0.17 \pm 0.04$ & $0.21 \pm 0.02$ & $0.56 \pm 0.35$ \\
Glu/GIn & $0.84 \pm 0.19^{\mathrm{a}}$ & $\mathbf{0 . 8 4} \pm 0.08^{\mathrm{b}}$ & $\mathbf{0 . 8 7} \pm 0.17^{\mathrm{b}}$ & $\mathbf{0 . 4 1} \pm 0.44^{\mathrm{b}}$ \\
\hline
\end{tabular}

Differences compared to control:

${ }_{\mathrm{p}}^{\mathrm{a}}<.025 ;{ }_{\mathrm{p}}^{\mathrm{b}}<.05$

Abbreviations are as for Table 4. Control data are taken from Huxtable et al., 1979.

\section{ACKNOWLEDGEMENTS}

These studies were supported by L'Association Canadienne de l'Ataxie de Friedreich.

\section{REFERENCES}

Azari J, Brumbaugh P, Huxtable RJ (1980) Prophylaxis by taurine in the heart of cardiomyopathic hamsters. J Mol Cell Cardiol 12: 1353-1366.

Bergstrom J, Furst P, Noree LO, Vinnars E (1974) Intracellular free amino acid concentration in human muscle tissue. J Appl Physiol 36: 693-697.

Barbeau A (1980) Friedreich's ataxia 1980: An overview of the physiopathology. Can J Neurol Sci 7: 455-468.

Barbeau A (1982) Friedreich's disease 1982: Etiologic hypothesis - a personal analysis. Can J Neurol Sci 9: 243-263.

Barbeau A, Melancon S, Huxtable RJ, Lemieux B (1982) Taurine and Friedreich's ataxia: an update. Advances in Exp Med Biol 139: 389-399.

Filla A, Butterworth RF, Barbeau A (1979) Pilot studies on membranes and some transport mechanisms in Friedreich's ataxia. Can J Neurol Sci 6: 285-289.

Huxtable RJ (1978) Cardiac pharmacology and cardiomyopathy in Friedreich's ataxia. Can J Neurol Sci 5: 83-91.

Huxtable RJ, Azari J, Reisine T, Johnson P, Yamamura H, Barbeau A (1979) Regional distribution of amino acids in Friedreich's ataxia brains. Can J Neurol Sci 6: 255-258. 
Lamarche JB, Côté M, Lemieux B (1980) The cardiomyopathy of Friedreich's ataxia: morphological observation in 3 cases. Can $J$ Neurol Sci 7: 389-396.

Lyengar GV, Kollmer WE, Bowen HJM (1978) The elemental composition of human tissue and body fluids. Verlag Chemie, Weinheim, New York.
Sanchez-Casis G, Côté M, Barbeau A (1976) Pathology of the heart in Friedreich's ataxia: Review of the literature and report of one case. Can J Neurol Sci 349-354.

van Gelder NM (1978) Taurine, the compartmentalized metabolism of glutamic acid, and the epilepsies. Can J Physiol Pharmacol 56: 362-374. 